\begin{tabular}{|c|c|}
\hline $\begin{array}{c}\text { eISSN: } 2655-8688 \\
\text { http://jurnal.stikes-sitihajar.ac.id/index.php/jhsp } \\
\text { hal: } 72-78\end{array}$ & $\begin{array}{c}\text { pISSN: 2548-3943 } \\
\text { received April, Accepted April, Publish Juni } \\
\text { Volume 1, Nomor } 2 \text { - } 2019\end{array}$ \\
\hline
\end{tabular}

\title{
Prediksi Kadar Glukosa Darah Terhadap Mortalitas Pasien di RSUP H. Adam Malik Medan
}

\author{
Elsarika Damanik ${ }^{1}$, Normi Parida Sipayung ${ }^{1}$, \\ ${ }^{1}$ Fakultas Farmasi dan Ilmu Kesehatan Universitas Sari Mutiara Indonesia \\ Email: elsadamanik78@yahoo.com
}

\begin{abstract}
ABSTRAK
Pendahuluan: Kadar glukosa darah merupakan hal penting dalam tubuh manusia karena untuk menunjang kesehatan, sehingga dapat melakukan aktivitas kerja dengan baik. Tindakan awal pada penderita kadar glukosa darah yang mengalami cedera kepala sangat menentukan hasil akhir di rumah sakit. Pasien yang tidak dapat mempertahankan kadar glukosa darahnya dalam kurun waktu 24 jam pertama dalam perawatan dapat mengakibatkan hal buruk pada akhirnya, bahkan dapat meningkatkan angka mortalitas yang disebabkan kadar glukosa darah. Tujuan: Penelitian ini bertujuan untuk mengnalisis prediksi kadar glukosa darah terhadap mortalitas pasien di RSUP H. Adam Malik Medan. Metode: Dalam penelitian ini penulis menggunakan analitik observasional dengan desain studi kohort retrospektif. Populasi dalam penelitian ini adalah seluruh pasien kadar glukosa darah tinggi yang mengalami cedera kepala pada Instalasi Gawat Darurat (IGD) RSUP H. Adam Malik Medan dan menggunakan purposive sampling sehingga terpilih 40 pasien kadar glukosa darah tinggi dengan cedera kepala. Hasil: Berdasarkan hasil tabulasi data menggunakan uji chi-square, mortalitas lebih rentan terjadi pada pasien yang memiliki kadar glukosa darah $>145 \mathrm{mg} / \mathrm{dl}$ dengan $\mathrm{p}$ value 0,00 dan odd ratio 0,18 . Kesimpulan: Pasien cedera kepala berat yang mengidap kadar glukosa darah $>145 \mathrm{mg} / \mathrm{dl}$ rentan meninggal, namun tidak memungkiri mortalitas pada pasien yang memiliki kadar glukosa darah $<145 \mathrm{mg} / \mathrm{dl}$ akibat cedera kepala berat.
\end{abstract}

Keywords: Mortalitas, Kadar Glukosa Darah, Cedera Kepala

\section{Blood Glucose Level Prediction on Patient Mortality at RSUP H. Adam Malik Medan}

\begin{abstract}
Introduction: Blood glucose levels are important in the human body because to support health so that they can do work activities properly. The initial action in patients with blood glucose levels who experience a head injury determines the outcome in the hospital. Patients who cannot maintain their blood glucose levels within the first 24 hours of treatment can cause a bad outcome, in the end, even increasing the mortality rate due to blood glucose levels. Aims: This study aims to analyze the predictions of blood glucose levels on patient mortality at $H$. Adam Malik Hospital in Medan. Methods: In this study, the authors used observational analytic with a retrospective cohort study design. The population in this study were all patients with high blood glucose levels who suffered head injuries in the Emergency Room (IGD) of H. Adam Malik Hospital in Medan and used purposive sampling so that 40 patients selected for high blood glucose levels with a head injury. Results: Based on the tabulation result using chi-square test shows that mortality was more prone to occur in patients who had blood glucose levels> $145 \mathrm{mg} / \mathrm{dl}$ with p-value 0.00 and odds ratio of 0.18. Conclusion: So in conclusion, a severe head injury patients who have blood glucose levels $>145 \mathrm{mg} / \mathrm{dl}$ are prone to death but do not deny mortality in patients who have blood glucose levels $<145 \mathrm{mg} / \mathrm{dl}$ due to a severe head injury.
\end{abstract}

Keywords: Mortality, Blood Glucose Level, Head Injury 


\section{Pendahuluan}

Kadar glukosa darah merupakan hal penting untuk kesehatan tubuh manusia serta menunjang aktivitas kinerja (Chatterjee, Davies and Tarigopula, 2017) (Nguyen et al., 2009). Selain itu kadar glukosa darah yang dimiliki manusia tidak dapat ditentukan dalam satu waktu dan hitungan baku (Wang and Lee, 2015) (Diabetes.co.uk, 2018). Hal tersebut disebabkan adanya perbedaan kadar glukosa darah pada saat sebelum dan setelah makan maupun pada saat kondisi tidur (Gupta and Kalra, 2016). Penyebab dari kadar glukosa darah yang tidak normal juga variative, namun biasanya akan melonjak naik pada saat dehidrasi, di pagi hari (biasa disebut fenomena fajar), kurang tidur, suhu ekstrem, atau karena terlalu banyak mengonsumsi kafein (Webber, Charlton and Johns, 2015) (Chuang, Yan and Cheng, 2010).

Kadar glukosa darah dalam batas normal yakni $<145 \mathrm{mg} / \mathrm{dl}$, sedangkan kadar glukosa darah $>145 \mathrm{mg} / \mathrm{dl}$ dikategorikan tinggi (Clarke and Foster, 2012) (He and MacGregor, 2015). Banyak akibat yang dapat ditimbulkan dari tingginya kadar glukosa darah seseorang, seperti dapat mengurangi efektivitas aktivitas seseorang (mudah Lelah), menimbulkan komplikasi hiperglikemia, neuropati (kerusakan saraf), dan kerusakan-kerusakan organ tubuh lainnya (Bray, 2013). Maka dari itu setiap orang perlu untuk mengontrol kadar glukosa darah yang dimilikinya (Nseir, Nassar and Assy, 2010).

Cedera kepala merupakan luka pada bagian kepala yang dapat mengakibatkan terganggunya fungsi otak akibat pukulan atau sentakan keras (Souza et al., 2016). Hal ini perlu untuk segera mendapatkan penanganan medis, karena dapat menyebabkan pendarahan, robeknya jaringan, bahkan hal fatal lainnya sepeti kematian (Mathur et al., 2016).

Tingkat keparahan cedera kepala pada pasien yang memiliki kadar glukosa darah tinggi yakni hiperglikemia, hal ini dapat menyebabkan komplikasi serius seperti koma diabetik dll. Tidak hanya hal tersebut, namun hiperglekemia dapat memicu komplikasi lainnya bahkan dapat menyebabkan mortalitas (Wing and James, 2013). Outcome yang buruk bisa terjadi pada pasien yang memiliki kadar glukosa darah yang tidak dapat dipertahanakan (maintainance) dalam 24 jam pertama masa perawatan, atau dapat menghambat penyembuhan dan bahkan terjadi mortalitasi pasien akibat cedera kepala berat (Kinoshita et al., 2002); (Melo et al., 2010).

Disisi lain, cedera kepala merupakan kasus yang sering ditemukan pada bagian Instalasi Gawat Darurat (IGD) di beberapa rumah sakit (Cole, 2009); (Tuckett et al., 2014); (Perry, Macias Tejada and Melady, 2018). Hampir 20\% diantara pengunjung Instalasi Gawat (IGD) merupakan pasien cedera kepala berat dan sebagian besarnya berusia dibawah 45 tahun (Cohen et al., 2007); (Sergides et al., 2006); (Richmond and Aitken, 2011). Seiring meningkatkan kejadian kecelakaan, semakin bertambah pula kejadian cedera kepala pada setiap tahunnya. Berdasarkan penelitian yang dilakukan oleh Feigin, et al (2012) bahwasannya terdapat 790 kasus cedera kepala yang dapat ditemukan pada IGD rumah sakit New Zealand dari 100.000 populasi yang ada. Disamping itu national Institute for Health and Clinical Exellence (NICE) (2007) dan Scottish Intercollegiate Guidelines Network (SIGN) (2009) juga menyatakan hal serupa, bahwa di scotlandia terjadi sebanyak 100.000 kasus cedera kepala pertahun pada IGD suatu rumahsakit. Ditambah dengan pernyataan 40\% kematian yang ada di Amerika Serikat diperkirakan karena cedera kepala. Oleh sebab itu cederea kepala menjadi masalah yang global (Benua Amerika, Eropa, maupun Asia) (Andri, 2011).

Tingkat pertahanan (survival rate) dan manajemen pasien cedera kepala akan berbeda-beda. Pada kasus cedera kepala berat, pasien memiliki survival rate yang lebih rendah daripada cedera kepada sedang dan cedera kepala ringan (Riccardi et al., 
2013); (Fabbri et al., 2010). Penanganan yang diberikan pada cedera kepala berat juga harus mendalam untuk mengurangi terlewatinya evaluasi unsur vital (resusitasi, anamnesis, pemeriksaan fisik, dan neurologi) (FKUI-RSCM, 2001). Untuk memanajemen penanganan yang baik pada pasien cedera kepala dimulai pada tempat kejadian, dalam transportasi, sesampainya di Instalasi Gawat Darurat (IGD) hingga pelaksanaan terapi definitive. Penanganan awal pada pasien cedera kepala dapat mempengaruhi hasil akhirnya. Selain itu juga dapat mengurangi mortalitas akibat cedera kepala.

Berdasarkan pemaparan diatas, penelitian ini bertujuan untuk menganalisis prediksi kadar glukosa darah terhadap mortalitas pasien yang mengalami cedera kepala di Rumah Sakit Umum H. Adam Malik medan.

\section{Metode Penelitian}

Penelitian ini bersifat analitik observasional dengan design studi kohort retrospektif. Faktor resiko dan efek suatu subjek akan diamati dalam waktu sesaat pada masa lampau, dengan catatan menggunakan data sekunder. Populasi yang diambil dalam penelitian ini adalah seluruh pasien yang mengalami cedera kepala berat pada IGD RSUP H. Adam Malik Medan pada tahun 2016 dan 2017, yakni 325 pasien. Untuk menentukan pasien sebagai sampel menggunakan purposive sampling dengan menentukan kriteria inklusi yakni score GCS $\leq 8$ dan mendapatkan 40 pasien. Tempat dan waktu penelitiannya yakni di IGD RSUP H. Adam Malik Medan pada Februari-September 2018.

Untuk mengumpulkan data, penulis menggunakan lembar observasi karakteristik demografi responden sebagai instrument penelitian. Hal ini bertujuan untuk mengetahui kadar glukosa darah dan data mortalitas pasien. Kemudian untuk menganalisis hasil pengumpulan data penelitian ini menggunakan uji chi-square, yang bertujuan untuk mengetahui hubungan yang ada pada variabel bebas dan variabel terikat.

\section{Hasil Penelitian}

Tabel 1Distribusi Frekuensi Karakteristik Terhadap Pasien Cedera kepala berat di RSUP H. Adam Malik Medan

\begin{tabular}{lcc}
\hline Umur & F & \% \\
\hline 30 Tahun & 24 & 60 \\
\hline$>30-60$ & 14 & 40 \\
\hline Total & 40 & 100 \\
\hline $\begin{array}{c}\text { Jenis } \\
\text { Kelamin }\end{array}$ & & \\
\hline Perempuan & 11 & 27,5 \\
\hline Laki-laki & 29 & 72,5 \\
\hline Total & 40 & 100
\end{tabular}

Berdasarkan tabel diatas, sebagian besar dari pasien cedera kepala berat yang ada di IGD RS H. Adam Malik Medan 72,5\% diantaranya berjenis kelamin laki-laki yang berusia $\leq 30$ Tahun sebanyak $60 \%$.

Tabel 2 Distribusi Frekuensi Kadar Glukosa Darah pada Pasien Cedera kepala berat di RSUP H. Adam Malik Medan

\begin{tabular}{lcc}
\hline \multicolumn{1}{c}{ KGD } & f & \% \\
\hline$\unlhd 45 \mathrm{mg} / \mathrm{dl}$ & 3 & 7,5 \\
\hline$>145 \mathrm{mg} / \mathrm{dl}$ & 37 & 92,5 \\
\hline Total & 40 & 100 \\
\hline
\end{tabular}

Tabel diatas menunjukan bahwa mayoritas pasien cedera kepala berat memiliki Kadar Glukosa Darah >145 mg/dl, yakni 92,5\%.

Tabel 3 Distribusi Frekuensi Angka Mortalitas pada Pasien Cedera kepala berat dengan status Kadar Glukosa Darah yang dimiliki di RSUP H. Adam Malik Medan

\begin{tabular}{|c|c|c|c|c|c|c|c|}
\hline \multirow{3}{*}{ KGD } & \multicolumn{4}{|c|}{ Mortalitas } & \multicolumn{2}{|c|}{ Total } & \multirow{2}{*}{$\begin{array}{c}\text { Nilai } \\
p\end{array}$} \\
\hline & \multicolumn{2}{|c|}{ Meninggal } & \multicolumn{2}{|c|}{$\begin{array}{c}\text { Tidak } \\
\text { Meninggal }\end{array}$} & & & \\
\hline & $\mathrm{f}$ & $\%$ & $\mathrm{f}$ & $\%$ & $\mathrm{f}$ & $\%$ & \\
\hline $\begin{array}{c}\leq 45 \\
\mathrm{mg} / \mathrm{dl}\end{array}$ & 3 & 7,5 & 0 & 0 & 3 & 7,5 & 0,000 \\
\hline $\begin{array}{l}>145 \\
\mathrm{mg} / \mathrm{dl}\end{array}$ & 37 & 92,5 & 0 & 0 & 37 & $\begin{array}{c}92, \\
5\end{array}$ & \\
\hline
\end{tabular}


Berdasarkan tabel diatas, angka mortalitas pada pasien dengan cedera kepala berat berat sangat tinggi yakni dengan ditunjukannya semua responden yang meninggal akibat cedera kepala berat. Disamping itu $92,5 \%$ diantaranya memiliki Kadar Glukosa Darah >145 mg/dl.

\section{Pembahasan}

Setelah melakukan penelitian dan menganalisa serta menguji data sampel yang dikumpulkan, hasilnya menunjukan bahwa adanya hubungan yang signifikan antara kadar glukosa darah dengan angka mortalitas pada pasien cedera kepala berat. Bagian kepala merupakan bagian anggota tubuh yang penting karena terdapat otak dan saraf yang mengkoordinasikan kinerja organ tubuh lainnya. Cedera kepala juga bisa mengakibatkan penurutan tingkat kesadaran. Disamping itu, hentakan atau trauma di bagian kepala dapat menjadikan disfungsi pada beberapa saraf yang bisa mengakibatkan peningkatan kadar glukosa sehingga terjadi kerusakan serebral maupun sistemik yang dapat meningkatkan inflamasi (Cohen et al., 2007); (Shi et al., 2015); (Edema and Zweckberger, 2017).

Ketidakseimbangan antara elektrolit dan penurunan sistem imun ini terjadi karena adanya peningkatan kadar glukosa darah pada pasien cedera kepala berat, hal tersebut merupakan penyebab terjadinya mortalitas (Edema and Zweckberger, 2017). Disamping itu, penyebab dari kerusakan dan stress adalah katekolamin yang meningkatkan sekresi glukagon serta menghambat sekresi insulin (Adi Nugroho, 2010).

Seluruh pasien cedera kepala berat meninggal pada saat mendapat tindakan di Instalasi Gawat Darurat (IGD). Kemudian, 92,5\% diantaranya mengalami peningkatan kadar glukosa darah. Hal tersebut membuktikan bahwa prediksi kadar glukosa darah pasien cedera kepala berat dapat menentukan hasil akhir dari penanganan yang diberikan. Oleh sebab itu, pemeriksaan kadar glukosa darah merupakan hal yang wajib dilakukan pada pasien Instalasi Gawat Darurat. Hiperglikemia menjadi faktor yang dapat mempengaruhi angka mortalitas pada pasien cedera kepala (Suri, Haddani and Sinulingga, 2016). Pada 24 jam pertama saat pemberian tindakan, pasien cedera kepala berat harus dapat mempertahankan (maintainance) kadar glukosa darahnya. Jika pasien tidak dapat mempertahankan kadar glukosa tersebut maka dapat menyebabkan hasil akhir (outcome) yang buruk ataupuun memperlambat penyembuhan, bahkan meningkatkan angka mortalitas (Kinoshita et al., 2002); (Melo et al., 2010).

Banyak faktor yang dapat mempengaruhi outcome pasien cedera kepala berat, salah satunya manajemen tindakan yang diberikan pada pasien yang baik dan tepat. Namun, hasil dari penelitian yang telah dilakukan ini menunjukan bahwa peningkatan kadar glukosa darah yang terjadi pada pasien cedera kepala berat yang meningkatkan angka mortalitas tersebut (Shi et al., 2015); (Kafakimd et al., 2016).

\section{Kesimpulan}

Kesimpulan yang didapat dari hasil penelitian ini adalah adanya hubungan yang signifikan antara kadar glukosa darah dengan mortalitas pasien cedera kepala berat di RS. H. Adam Malik Medan, dengan $\mathrm{p}$ value 0,00 dan odd ratio 0,18 . Sebagian besar pasien cedera kepala berat mengalami peningkatan kadar glukosa darah pada 24 jam pertama dalam penanganan sehingga mengakibatkan meninggalnya pasien.

\section{Ucapan Terima Kasih}

Peneliti Mengucapkan terima kasih kepada Direktorat Riset dan Pengabdian Masyarakat, Direktorat Jenderal Penguatan Riset dan Pengembangan, Kementerian Riset, Teknologi dan Pendidikan Tinggi sesuai dengan kontrak penelitian Nomor: 131/K1.1/LT.1/2018 atas bantuan dana Penelitian Dosen Pemula 


\section{Referensi}

Adi Nugroho, S. (2010) 'Hubungan Antara Tingkat Stres dengan Kadar Gula Draah pada Pasien Diabetes Mellitus di Wilayah Kerja Puskesmas Sukoharjo I Kabupaten Sukoharjo', Universitas Muhammadiyah Semarang, pp. 43-51. doi: 10.1152/ajplung.00315.2013.

Andri (2011) Cedera Kepala Bisa Bikin Gangguan Jiwa, kompas. Available at:

https://lifestyle.kompas.com/read/20 11/07/06/0538596/cedera.kepala.bisa .bikin.gangguan.jiwa (Accessed: 11 August 2018).

Bray, G. A. (2013) 'Energy and Fructose From Beverages Sweetened With Sugar or High-Fructose Corn Syrup Pose a Health Risk for Some People', Advances in Nutrition: An International Review Journal. doi: 10.3945/an.112.002816.

Chatterjee, S., Davies, M. J. and Tarigopula, G. (2017) 'Pharmacological control of blood sugar', Anaesthesia and Intensive Care Medicine. doi: 10.1016/j.mpaic.2017.06.017.

Chuang, K. J., Yan, Y. H. and Cheng, T. J. (2010) 'Effect of air pollution on blood pressure, blood lipids, and blood sugar: A population-based approach', Journal of Occupational and Environmental Medicine. doi: 10.1097/JOM.0b013e3181ceff7a.

Clarke, S. F. and Foster, J. R. (2012) 'A history of blood glucose meters and their role in self-monitoring of diabetes mellitus', British Journal of Biomedical Science. doi: 10.1080/09674845.2012.12002443.

Cohen, B. A. et al. (2007) 'Proton MR spectroscopy and MRI-volumetry in mild traumatic brain injury', AJNR. American journal of neuroradiology, 28(5), pp. 907-13. Available at: http://www.ncbi.nlm.nih.gov/pubme d/17494667 (Accessed: 11 November 2018).
Cole, E. (2009) Trauma Care: initial assessment and management in the emergency department, Respiratory Care.

Diabetes.co.uk (2018) Normal and Diabetic Blood Sugar Level Ranges - Blood Sugar Levels for Diabetes, diabetes.co.uk. Available at: https://www.diabetes.co.uk/diabetes_ care/blood-sugar-level-ranges.html (Accessed: 2 August 2018).

Edema, B. and Zweckberger, K. (2017) 'traumatic Brain Injury and Edema Treatment', Brain Edema, pp. 457476. doi: 10.1016/B978-0-12803196-4.00023-0.

Fabbri, A. et al. (2010) 'Predicting intracranial lesions by antiplatelet agents in subjects with mild head injury', Journal of Neurology, Neurosurgery and Psychiatry, 81(11), pp. 1275-1279. doi: 10.1136/jnnp.2009.197467.

FKUI-RSCM (2001) Sinopsis Ilmu Bedah Saraf. Cetakan 1. Jakarta: Sagung Seto.

Gupta, Y. and Kalra, B. (2016) 'Screening and diagnosis of gestational diabetes mellitus', JPMA. The Journal of the Pakistan Medical Association. doi: 10.7860/JCDR/2016/17588.7689.

He, F. J. and MacGregor, G. A. (2015) 'Salt and sugar: their effects on blood pressure', Pflugers Archiv European Journal of Physiology. doi: 10.1007/s00424-014-1677-x.

Kafakimd, S. B. et al. (2016) 'Hyperglycemia: A predictor of death in severe head injury patients', Clinical Medicine Insights: Endocrinology and Diabetes, 9, pp. 43-46. doi: 10.4137/CMED.S40330.

Kinoshita, K. et al. (2002) 'Effect of Posttraumatic Hyperglycemia on Contusion Volume and Neutrophil Accumulation after Moderate FluidPercussion Brain Injury in Rats', Journal of Neurotrauma, 19(6), pp. 681-692. doi: $10.1089 / 08977150260139075$. 
Kurniawan, I., \& Sulaiman, S. (2019). Hubungan Olahraga, Stress dan Pola Makan dengan Tingkat Hipertensi di Posyandu Lansia di Kelurahan Sudirejo I Kecamatan Medan Kota. Journal of Health Science and Physiotherapy, 1(1), 10-17. https://doi.org/10.25311/hsj.v1i1.4

Mathur, R. K. et al. (2016) 'Head injury A leading cause of mortality in road traffic accidents', Medico-Legal Update. doi: 10.5958/09741283.2016.00048.7.

Melo, J. R. T. et al. (2010) 'Acute hyperglycemia is a reliable outcome predictor in children with severe traumatic brain injury', Acta Neurochirurgica, 152(9), pp. 15591565. doi: 10.1007/s00701-0100680-z.

Nguyen, S. et al. (2009) 'Sugar-Sweetened Nuryatno, N. (2019). Hubungan Dukungan Keluarga dengan Kualitas Hidup Pasien Diabetes Mellitus Tipe 2 di Puskesmas Helvetia Medan. Journal of Health Science and Physiotherapy, 1(1), 18-24. https://doi.org/10.25311/hsj.v1i1.5

Beverages, Serum Uric Acid, and Blood Pressure in Adolescents', Journal of Pediatrics. doi: 10.1016/j.jpeds.2009.01.015.

Nseir, W., Nassar, F. and Assy, N. (2010) 'Soft Drinks Consumption and Nonalcoholic Fatty Liver Disease', World Journal of Gastroenterology, 16(21), pp. 2579-2588. doi: 10.3748/wjg.v16.i21.2579.

Pasaribu, I., Sulaiman, S., \& Erwansyah, R. (2019). Keefektifan Penggunaan ELearning Berbasis Google Docs Terhadap Hasil Belajar Mahasiswa Pada Mata Kuliah Teknologi Informasi Di Stikes Siti Hajar. Journal of Health Science and Physiotherapy, 1(1), 29-31. https://doi.org/10.25311/hsj.v1i1.7

Perry, A., Macias Tejada, J. and Melady, D. (2018) 'An Approach to the Older Patient in the Emergency
Department', Clinics in Geriatric Medicine, 34(3), pp. 299-311. doi: 10.1016/j.cger.2018.03.001.

Riccardi, A. et al. (2013) 'Minor head injury in the elderly at very low risk: A retrospective study of 6 years in an Emergency Department (ED)', American Journal of Emergency Medicine, 31(1), pp. 37-41. doi: 10.1016/j.ajem.2012.05.023.

Richmond, T. S. and Aitken, L. M. (2011) 'A model to advance nursing science in trauma practice and injury outcomes research', Journal of Advanced Nursing, 67(12), pp. 27412753. doi: 10.1111/j.13652648.2011.05749.x.

Sergides, I. G. et al. (2006) 'Is the recommended target of 4 hours from head injury to emergency craniotomy achievable?', British Journal of Neurosurgery, 20(5), pp. 301-305. doi: 10.1080/02688690600999976.

Shi, J. et al. (2015) 'Review: Traumatic brain injury and hyperglycemia, a potentially modifiable risk factor', Oncotarget, 7(43), pp. 71052-71061. doi: 10.18632/oncotarget.11958.

Souza, B. D. S. N. et al. (2016) 'Soft Drink Consumption, Mainly Diet Ones, is Associated with Increased Blood Pressure in Adolescents', Journal of Hypertension. doi: 10.1097/HJH.0000000000000800.

Suri, M. H., Haddani, H. and Sinulingga, S. (2016) 'Hubungan Karakteristik, Hiperglikemi, dan Kerusakan Saraf Pasien Neuropati Diabetik di RSMH Palembang Periode 1 Januari 2013 Sampai Dengan 30 November 2014', Jurnal Kedokteran dan Kesehatan, 2(3), pp. 305-310. doi: 10.1089/107555304323062275.

Tuckett, J. W. et al. (2014) 'Maxillofacial trauma in the emergency department: A review', Surgeon, pp. 106-114. doi: 10.1016/j.surge.2013.07.001.

Wang, H. C. and Lee, A. R. (2015) 'Recent developments in blood glucose sensors', Journal of Food and Drug 
Analysis.

doi:

10.1016/j.jfda.2014.12.001.

Webber, J., Charlton, M. and Johns, N. (2015) 'Diabetes in pregnancy: management of diabetes and its complications from preconception to the postnatal period (NG3)', British Journal of Diabetes. doi: 10.15277/bjdvd.2015.029.

Wing, R. and James, C. (2013) 'Pediatric head injury and concussion', Emergency Medicine Clinics of North America.

doi: 10.1016/j.emc.2013.05. 